\title{
JYOMO'S LIFE OF WORK
}

What's the matter with me? I don't think about finding good, sweet things to eat like others do. Or about nice things to wear. Only one thing: "Will this work or that work not get done? What work needs to be done?" That's the only thing I think about.

Jyomo, Stupahill, 1977

TUlaram: Tell us, "This is how I've gone about; this is how many calendaryears I've seen. ..."

JYOм0: I don't know how old I am in calendar-years. To know how many calendar-years-oh!-I only know in cycle-years.

KSM: You know the cycle-year?

JYомо: I'm of the cycle-year of the monkey-monkey. This time, well, what can I do? This time I will have lived to reach four, even almost five of the twelve-year cycles. That's a lot! I have nearly achieved my fifth twelve-year cycle. ${ }^{1}$

Jyomo is the wife of the eldest of the three brothers who are Mondzom's surviving grandsons. Because of her senior position in the sublineage, she is Amagren (Eldest Mother) or Anyigren (Eldest Aunt-mother-in-law) to much of the village. She is an extremely hard worker and frequently undertakes the most arduous tasks herself rather than ask anyone else to do them. She was sought in her current marriage chiefly because of the household's need for

1. Elided here are discussions of Jyomo's age according to the various calendrical systems and of her natal kin, their birth orders, and their deaths. 
more laborers. Reserved but influential, Jyomo has become an astute manager of one of the most complex households in the village.

Although she is not by any means a gloomy person, Jyomo clearly takes the events of life more seriously than many. Her first marriage was a very unhappy one and ended in divorce. When she married into her present husband's household, she had no close kin of her own there, or, indeed, anywhere nearby. When she arrived, her husband already had one wife, whom he apparently kept trying to convince to move to live with him, without much success; during this time, his relations with Jyomo seem to have been often strained. Now that she is well settled as his only wife, Jyomo maintains warm social ties of her own in many directions. She enjoys having her married daughters or her sister's daughter visit. She is actively interested in other people's news, although she is herself restrained when it comes to gossip. In all her relations, she seems genuinely concerned about others, their doings, and their difficulties.

Her husband is a prominent force in the village and in the entire region, both because of his position at the head of a powerful lineage and because of his own political energies. Jyomo sometimes seems to stand in his shadow; certainly, her manner is much less imposing than his. She seldom speaks first and rarely argues. She is not given to the sharp banter that arises between the other two brothers and their spouses. Even when directly criticized by her husband, Jyomo rarely rises to his bait or engages in a verbal argument. This should not be mistaken for any weakness on her part: even in the face of her husband's authority, she nevertheless plies very much her own way. As do most Tamang wives, she controls the household purse strings, and she doesn't submit easily to her husband's ideas of where the money should go. She tempers his political activity by rarely relinquishing as much money as he says he will need.

Through all the waves of turmoil she has seen in her household, her community, and the entire Stupahill Tamang region, Jyomo has continued on her own way, utterly reliably and more or less unperturbed. Those who have her as an ally know they can rely on her unfailingly. Those with whom she does not agree are never confronted openly, but the disagreement remains there, unforgotten. Through everything, Jyomo shows a sharp awareness of her social obligations and sense of moral duty.

It was Jyomo who extended to me my first major social invitation-to accompany her on a somewhat lengthy local pilgrimage-and she remained a thoughtful senior advisor throughout my stays in the region. I acquired my first local identity in her house: David Holmberg came to be called a son there, and I then became Jyomo's eldest daughter-in-law.

Jyomo's interest in this life history project was keen from the beginning, but as with all things that interested her, she listened quietly to talk from all quarters, carefully collecting information until she was fully satisfied. Then she approached me herself one day to say that that afternoon was a good one 
for her to tell her story. It was a sad one, she said, that should be told but that would not make the hearer happy. If I would be ready, she would come to my house in the late afternoon and we could record. Present during Jyomo's narration, were:

Jyomo

KSM (courtesy daughter-in-law and younger clansister to Jyomo)

Tularam (classificatory younger brother to Jyomo)

\section{An unhappy marriage ends in divorce}

JYOмо: When I was twelve calendar-years old, I had been carried off to Firestone. After the wedding was done to one who was only twelve, I stayed for eight calendar-years. Then he brought in another wife. He would be contemptuous of me; I'd be beaten. I wouldn't be given food to eat, or clothes to wear. In order to endure, after enduring, I didn't stay. I came here.

I would have stayed there in Firestone, but ... every day, I'd get beaten, even on the trail. He would be jealous and cast the evil eye on me. "Go find yourself a husband you like," he'd say. With that kind of insulting talk, I didn't stay. That would have been eight calendar-years after the wedding had been done.

It didn't take me long in the Tamang community to learn that, although most Tamang women and men spend much of their adult life in stable and companionable marriages, divorce and remarriage are extremely common. Divorce is especially likely in young, childless first marriages. Almost all Tamang men and women will remarry if their partner dies, no matter how old they are. Among their Parbatiya neighbors, both divorce and the remarriage of widows have been strongly censured traditionally; these secondary unions (as the literature calls them) were definitely second-rate. Such ideas contributed strongly to orthodox Parbatiya disdain for Tamang and their marriage practices. Since the restoration of the monarchy in $195^{1}$ and even more so since the People's Movement of 1990, some sectors of Nepali society have been agitating for legal and social reform that would extend to Parbatiya women the same marital freedoms that Tamang women have always exercised.

Tamang marriage is more than the casual or transient union of two people, however; women and men neither enter nor leave marriages casually. There are complex arrangements for undoing marital alliances. Everyone I asked said that dissolving Tamang marriages involved a public ritual called "breaking of the sticks." Couples who were determined to separate would get a third party to hold a stick that had been scored in two places; if husband and wife each both broke off one end, the marriage was finished. Some people said that the broken pieces of stick would be placed in the 
house rafters, so that they could be rejoined should the couple decide to remarry. Neither I nor anyone I asked, however, had actually witnessed any real sticks being broken or cached away in attics. The breaking of the sticks seems to be a conventional phrase and metaphoric explanation but not, as far as I could ascertain, a real practice.

Whenever a marriage is terminated, public settlement of what are called the wedding expenses must be made. If the woman is the instigator of the divorce she (or her representative) must pay her husband between one and one hundred fifty Nepali rupees (in 1977) as dola, said to be the amount he would have to spend to find and marry another wife. If the man wants to end the marriage, it costs him more. If his wife has children, he must divide his property and provide her children with their share of the inheritance; even if there are no children and she is unopposed to the divorce, she is entitled to up to five hundred Nepali rupees as warchya settlement.

If adultery can be proven, the adulterant parties must pay the defrauded ones. Thus, if a married woman runs off with another man, she (or her new husband, or her own parents) must pay. If a married man takes up with another wife and his first wife is neither willing to become a co-wife, nor in a position to claim inheritances for minor children, she can still demand the adultery settlement of him (or his family, or his new wife and/or her family). Typically, adultery settlements are somewhat steeper and more bitterly negotiated than simple repayment (or prepayment) of wedding expenses.

In all divorce cases, all parties reclaim their own property. A woman is entitled to take anything she brought in as her dzo-property, including any offspring of livestock, interest collected on loans, or new property she obtained herself. But she must leave behind any goods acquired from her husband or his family, especially any gold jewelry they might have given her. Subsequent marriages are as respectable as original ones, regardless of the circumstances of the divorce, but negotiations can be bitter and tempers hot, so neither divorce nor remarriage is lightly undertaken.

JYомо: After breaking the marriage sticks, well, I came here. And then, well, that's how I had lived. In those earlier times, that's how it seems I lived. I couldn't tolerate my husband. I stayed even though I couldn't stand him. I would continue working in his fields; I'd keep on taking care of his animals. I stayed and carried on in that way; even though I couldn't stand it, I stayed. Even though I was beaten, I stayed. I stayed on and on in that way. For six or seven calendar-years, then, after eight calendar-years, I went and came here.

I worked hard there: I cut fodder and firewood; I worked in the irrigated fields; whatever I could do. I kept on and on doing things myself, after saying to myself it didn't matter whether I could stand it or not, I kept on working in the fields. In order to fulfill my allotted field tasks, myself, I 
stayed on working. But I couldn't stand it. But, then, after staying on like that, I went and came here.

Now, then, after breaking the divorce sticks, this time I really stayed, didn't I, after reaching here in marriage?

There, working and working in the fields, what? Well after all, my girlhood friends were there. Even in someone else's village, there were people I knew. I even went to cut fodder and firewood with someone else's children. I even went to the forest; I even worked in hard field labor. With my girlhood friends, there was so much affection, but now, where have they all gone? To someone else's village place. Not to your own village place. That was Firestone. I stayed because of the love of my girlhood friends.

Nowadays, one is Jundar's wife in Daughters' Pleasure, and the other was Old Soltang's fourthborn younger daughter. Well, I would go around with them with so much affection. Everywhere we went-to the other side of the valley, or this side, even in the forest, herding or whatever - there was so much affection with them. With the one called that Old Soltang's daughter, too, I went wandering all over with her so lovingly. I stayed a long time. Nowadays she's called K.P.'s junior wife, or something. Whatever she's called, whosoever's wife, now her house is way over across there. I stayed then because of that woman's great love for me, there in Firestone. Nowadays, she's K.P.'s junior wife, there in Earth's Hole.

TUlaram: She's of Earth's Hole ...

KSM: In Earth's Hole?

Jуомо: She's reached Earth's Hole in marriage. She went down to Earth's Hole. In Firestone, while we were all in Firestone, it was with those twono one else showed me any affection-but with those two-with Old Soltang's daughter. . . . Nowadays she's the one who's reached Earth's Hole in marriage; she's called K.P.'s wife ... and with that other one-with those two there was so much affection, going to the forest, going to collect firewood, going to work in the fields. It was with those two that I went around lovingly.

$$
\text { "Lingma Song"2 }
$$

[Name and] purify with incense! Purify with incense!

I will purify with incense!

I will purify for the local village divinities,

for the mother earth, with incense!

Hya hwai lingma! ${ }^{3}$ Come! Lingma!

Purifying for the mountain divinities [requires] juniper incense.

Hya hwai lingma! Come! Lingma!

[Name and] purify with incense! Purify with incense!

I will purify with incense!

2. A work song to which Jyomo referred. Jyomo is adamant that she does not sing, so we arranged to have this recorded and added afterwards.

3. The "Hya Hwai" (or "Song of the Hand") is a mythic creation song; lingma is the category of work songs. For a more detailed study of the "Hya Hwai," see March (1998). 
Purifying for the lowland divinities [requires] pine incense.

Hya hwai lingma! Come! Lingma!

[Name and] purify with incense! Purify with incense!

I will purify with incense!

Make the golden bright young men's mouths open [in song]!

Hya hwai lingma! Come! Lingma!

[Name and] purify with incense! Purify with incense!

I will purify with incense!

Make the golden bright young women's mouths open [in song]!

Hya hwai lingma! Come! Lingma!

[Name and] purify with incense! Purify with incense!

I will purify with incense!

Set the stalks of corn straight!

Hya hwai lingma! Come! Lingma!

[Name and] purify with incense! Purify with incense!

I will purify with incense!

Pull the stalks of weeds ${ }^{4}$ straight out!

Hya hwai lingma! Come! Lingma!

[Name and] purify with incense! Purify with incense!

I will purify with incense!

Purifying for the mountain divinities [requires] juniper incense.

Hya hwai lingma! Come! Lingma!

[Name and] purify with incense! Purify with incense!

I will purify with incense!

Purifying for the lowland divinities [requires] pine incense.

Hya hwai lingma! Come! Lingma!

[Name and] purify with incense! Purify with incense!

I will purify with incense!

Make the golden bright young men clever and agile.

Hya hwai lingma! Come! Lingma!

[Name and] purify with incense! Purify with incense!

I will purify with incense!

Make the golden bright young women's mouths open [in song].

Hya hwai lingma! Come! Lingma!

[Name and] purify with incense! Purify with incense!

I will purify with incense!

JYомо: In that way, I would stay even in a place where I was beaten, even though my girlhood friends would say, "If you were to leave, it would be OK, you know." All the while I went about there, my heart hurt. I would be beaten and I'd cry. Someone else would beat me and I'd cry. It would have been better to go away than to stay that way. I said to myself it was an intolerable place to be in since they beat me daily and, even so, I stayed on

4. The rhyming contrast in the original Tamang is between makai dongbo (trees of corn) and mraki dongbo (trees of weeds) and is far more satisfying. 
those eight calendar-years. And, then, well, that's how I went and came down here. I've stayed down here ever since.

But, well, when I was living with Father and Mother, I'd go around with my girlhood friends. Nowadays there's Syipa's Wife's Mother, for one, and, there, our uncle-father-in-law-the one called Middle Mugé . . .

TUlaram: Middle Mugé?

JYomo: Yes. Nowadays, that one's Partap's mother. With that one, too, with them-my daughter-in-law and my husband's elder sister-I would go around lovingly. I didn't go around with others much. I didn't have a lot of girlfriends to go around with lovingly. With that one, that Partap's Mother for one and, from the hamlet below, Syipa's Wife's Mother for another, I went around lovingly. . . .

[She drinks from the liquor I've offered her, but when I offer more says:] That's enough.

KsM: [Pressing a bit] A little more? They say your head will ache if you don't ...

Jуомо: No more now; I'll drink some more in a bit.

\section{Hospitality work}

All Tamang social events aspire to involve food and drink. Tamang people can and do drop by one another's houses casually, without any expectations of eating or drinking-especially when they are neighbors who see each other daily-but an offer of food and drink is the more common experience of social visits. Because I had asked for the special favor of these recording sessions, it was appropriate for me to have drinks, snacks, and tobacco on hand. The preferred drinks were $j i$, a fermented millet beer, and raksi, a clear liquor very like Japanese sake, distilled from the beer mash. Tamang preferred ji on a hot afternoon after working in the fields. It was served by whisking water with the beer mash, and without straining out the mash, so it was filling as well as refreshing. It was also considered slightly more informal. Raksi, however, could be served on any occasion. It had about the potency of wine and, because it was not mixed with water, did not present the otherwise inevitable risks associated with drinking unboiled water anywhere in Nepal. I found it smooth tasting from the first, and although I welcomed a bowl before dinner in the evening, I never entirely accustomed myself to the practice of drinking it first thing in the morning on festival days.

Raksi was served in the small bronze drinking bowls that were part of the symbolic core of a woman's inheritance. The drink was to be served cold in summer, heated in winter, and accompanied by some kind of $k u$-a spicy snack of beans, popcorn, vegetables, or meat. In the mid-197os, it was also common practice to share cigarettes. In Tamang language, tobaccotamaku—is also called tam-ki-ku, "the accompaniment of talk," and the bub- 
bling of water pipes regularly punctuated conversation on porches throughout the community. Although few people smoked an entire cigarette by themselves, cigarettes with such alluring names as Hope and Rhinoceros (the cheapest) and Yak (the fanciest) were then welcome signs of hospitality.

By the 1990s, a local anti-smoking campaign had cut down on tobacco consumption considerably and tea was available in the village as an alternative drink. To many who have worked in Nepal, the idea of a village without chiya, the sweet milk tea that is found throughout the subcontinent, is almost inconceivable. The Stupahill Tamang, however, did not drink it in their homes. The leaves, spices, and sugar needed to make tea were luxuries beyond the cash means of almost everyone. Instead, they would offer home-brewed jibeer or raksi-liquor to those who drank alcohol and hot, fresh milk or cooled buttermilk to those who did not.

Proper etiquette involved offering at least one refill of drink and, usually, a second serving of the snack. People who didn't want to drink or eat much learned to leave their bowls largely untouched until after the refill round. Whether because of the need for grain for food, or the effort involved in brewing and distilling, or social pressures against excessive consumption, drunkenness in Stupahill was rare and almost exclusively the domain of young men on festival days. One bowl or two, accompanied by a spicy snack, was the Tamang avenue to easy conversation, relaxation, and companionship.

JYOMO: I would go to the forest with those girlhood friends, and to do exchange labor in the fields. We'd go around working. That's how we went around, wherever, whatever work there was to do.

Lovingly though all that was, I didn't go to festivals the same as all my friends. Oh, I got to go and see now and again: I would go to see Red Powder Festival for one, and I went to see Cedarforest Festival once. But I can tell you that I didn't go to festivals all over the place like they do nowadays, not when I was young. I only went after coming up here in marriage, like to the Horse Festival! But at that time I didn't go to festivals. I didn't go to see them; I didn't even go to see them. Then it wasn't like nowadays, when friends say, "Lo! Lo! Let's go!" and they go off. My friends, well, they weren't like that. I'd go see that Red Powder Festival for just a little while, and that Mud Festival for example, or Cedarforest Festival for another. Those were the festivals I'd been in a position to see. I saw those; I didn't see any other festivals, but I saw those.

That's how I went around. If I called them friends, it was because we would work together and, finding ourselves working together, we'd exchange labor. Sometimes we'd go to the forest to cut fodder or firewood. All we'd do was work in the fields and exchange labor. That's all.

Tamang are peasant farmers, and, as Tschirto said, "Up here, we farming people have to do so much-so much!-work." They support themselves by a 
mix of subsistence farming, herding, trading, weaving, wage labor, exchange labor, borrowing, lending, and sharing. All Tamang are well aware that making an adequate living in their fragile mountain environment is not easy. As Jyomo said, "if the work doesn't get done, no one eats."

\section{Weaving work}

In order to take me seriously, the Tamang had to find a way to construe what I did as work. In their eyes, it was important that David and I were willing to carry water, wash clothes, cook food, and even, with what were uniformly adjudged to be poor results, try our hands at various agricultural labors. To Stupahill women, it was particularly important that I learn to weave. Weaving was, in practice and in myth, central to western Tamang ideas about women's and men's rightful work in the world.

The moral importance of weaving is apparent in the "Song of the Loom." 5 This song was said to have originated as a competition between a brother and a sister. The sister was learning to weave, and proud of her womanly work, while her brother was proud of learning to read and write so that he could become a lama. Setar told me that the brother was trying to get the better of his sister by extolling the virtues of his work, but that she wouldn't be put down. She matched his challenges item for item; for each piece of the lama's paraphernalia he sang about, she retorted by singing about a part of her loom. Since the beginning of Tamang time, asserts this song, work has bound men and women to their respective roles.

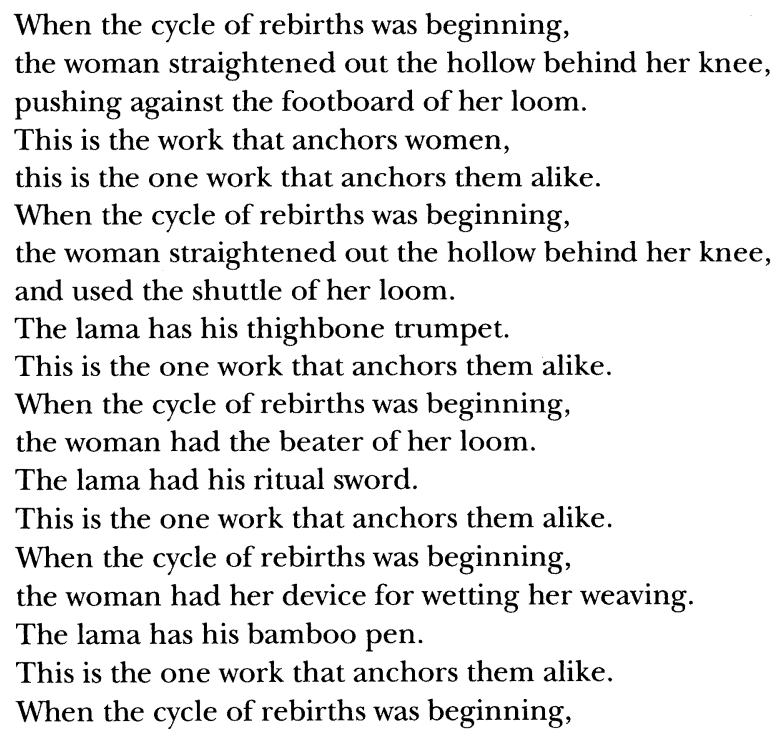

5. The "Thara-i Namtar"; see also March (1983). 
the woman had her device for keeping her selvages straight.

The lama has his printing of books with woodblocks.

This is the one work that anchors them alike.

When the cycle of rebirths was beginning,

the woman had lease and hettle rods.

The lama has his walking stick.

This is the one work that anchors them alike.

It was Tikiri who offered to teach me to weave and who gave me a credible specific personal identity in the community. She instructed me in what was then the defining womanly art and, while she was teaching me one day, announced that I was her eldest daughter. This made Tschirto and Mlangdzom my younger sisters and clarified my relations with everyone else in Stupahill. Whereas before I had been Daughter-in-law, Younger Sister, or Elder Sister to everyone, now I was Eldest Aunt to Purngi's and Nhanu's children and Elder Mother to Suryaman's children. Although Tikiri's naming me Eldest Daughter gave me a clear position in Stupahill, and I learned some weaving, my notebooks, pencils, and tape recorder, and the writer's bump that I had on the middle finger of my right hand, still defined my work and set me apart.

When one visitor to Stupahill expressed his envy of my good fortune in "not having to work," he was loudly contradicted by Jyomo's husband: "Our women work with sickle, tumpline, and carrying basket. You see her pencil; that's her sickle. And her notebooks and tape recorder are her tumpline and carrying baskets." In the Tamang world of Stupahill, where everyone must work to eat, it was important to people's understanding of me that: I was willing to work as they knew it; I wasn't very skillful at work as they knew it; and, I had calluses on my fingers from the work I did know-writing.

Although my writing work differentiated me from the westerners of Tamang imagination-who never have to work to eat-there were no illusions about whose work was harder. I only plowed paper, sowed endless questions, and harvested words. The situation of the Tamang women was explained by Purngi: "Here, oh, these days it all depends on working, and working is hard on me these days. But if you don't work, you'll be a hungry rascal. When has it ever really been easy for peasant farmers, eh?" So people work, and work hard, to eat. Tschirto is blunt, "Whatever else might be said, one has to work; one has to eat."

The main crops in this region are corn (maize) and millet, which are intercropped all up and down elaborately terraced hillsides. Wealthier families also have irrigated fields below springs or along the river basin where they can grow wet rice and winter wheat. In addition, everyone grows smaller quantities of beans, lentils (pulses), various squashes, some vegetables, chili peppers, onions, garlic, peanut (groundnut), soybeans, amaranth, and flowers. Many people have a few fruit trees as well, and most also grow mustard 
for oil. A few are experimenting with new cash possibilities in crops like coffee, apples, ginger, and different vegetables.

\section{Work exchange groups}

As a whole, the village of Stupahill was self-sufficient in the late 1970s, producing more or less enough of everything it needed. But not everyone could produce or profit equally. As in most peasant communities, in Stupahill, land is what separates rich from poor. In 1977, about half the households in the village had enough land to produce what they needed to feed themselves and to sell or trade for their other needs. To make ends meet, these households had to balance mouths, land, and work carefully. Two strategies were particularly important to these marginally self-sufficient houses: first, to expand the family workforce through exchange labor; and second, to send some mouths out into wage labor.

Exchanging labor is an essential work strategy in Stupahill. In a system of rotational labor called nang phapa phopa, groups of eight to fifteen neighbors, kin, and friends agree to work each other's fields in rotation. This allows each house to benefit from a larger workforce than it can assemble by other means. A household's normal workforce would consist of all the able residents of that house, with the possible addition of married daughters temporarily returned from their husbands' houses. But at moments of peak agricultural labor, this is often not enough.

In these mid-hills of Nepal, the agricultural cycle can vary by as much as three to four weeks across the different elevations and exposures of fields in a single village. A cornfield near the river bottom may need to be hoed and weeded on the tenth of the month, while at middle elevations, the same first cultivation of corn may occur on the fourth of the next month. By pooling their labor, even modest households can ·put more land into intensive agricultural production than their own workforce could otherwise handle. Households with more people than their lands can feed may send some of their excess workers out in paid day labor, but they neither need nor can afford large nang work gangs. Conversely, the large landholding families rarely have workers to spare for nang phapa phopa exchanges; they need much more work done than they have workers, so they must pay for the help of additional day-workers, either in cash or in kind. The rotational nang exchange can only be successfully utilized by families that have only slightly more land than labor.

The pot of this collective labor is sweetened as one household offers another beer and snacks to work in its fields. Although the work is hard, there is a feeling of plenty and promise in these balanced and rewarding exchanges among equals. Most women, when they spoke of nang phapa phopa, said little about its economic value but talked about how much more pleasant it 
made the work. "Whatever I do, I have to work, I have to go out to work in the fields," said Tschirto, "and so, that's how I went about working in the labor exchanges with a big friendly group like that." Women who live and work together in these groups often become each other's best friends.

In the mid-197os, about five percent of the households in Stupahill had more land than they needed to feed themselves, but they were often short of labor to work all their lands. They could either rent their surplus lands out to marginally landed farmers or they could hire day laborers and continue to manage their own lands. ${ }^{6}$ Although such arrangements were primarily a means of protecting the rights of the larger landholding families, they also fed the rest of the community. The large landholding families' ties to all but the few caste blacksmith families were reinforced by marriage and other traditional forms of Tamang exchange. This connectedness created a strong cultural flavor of equality, although an aftertaste of the underlying inequity remained.

The poorest families had to work in wage labor both in and out of the village, particularly in porterage. Their survival was often dependent on the work of women. Poor or landless women portered for local and long-distance trade; undertook complex borrowing and lending arrangements involving goods, grain, money, and animals; and, especially, wove traditional Tamang cloth. Tikiri, for example, "wove, wove, and only wove ... throughout the whole cold, dry season I'd weave fifty gallon-measures' worth."7 The most enterprising women of these narratives managed to use their trading, herding, lending, and weaving skills to pull their families away from the brink of starvation and buy themselves lands and herds, and even to build substantial houses of their own.

\section{Farming work}

Regardless of how much land people have or who owns it, agriculture structures the basic pattern of work in Tamang villages and shapes Tamang conceptions of the day and the year. The period of intensive agriculture begins as the monsoon rains arrive in mid-April. It ends in October or November, as the last crops are harvested, a couple of months after the rains have stopped. Ritual and social life, however, flourish from October until mid-April. These two faces of the Tamang year do not exactly correspond to the annual alternation in weather from rainy to dry, since agricultural efforts last longer than the monsoon. Nevertheless, the Tamang think of the year in two parts: the

6. As national regulation of tenant rights increased, these households became less likely to rent their land. Instead, they employed temporary workers from other households in the community, including the approximately $35 \%$ of households without enough land to feed themselves and the $5 \%$ with no land at all.

7. Here, Tikiri means that she earned fifty gallon-measures of grain in exchange for weaving during the slack agricultural season. 
(mostly wet) yarsung season for farmwork, and the (dry) mharsung season for feasts and other ritual, leisure, and social events. ${ }^{8}$

Just before the monsoon rains begin in earnest, men go out to plow the terraces, borrowing plow animals if they have none of their own, while other household members work to repair terrace walls and transport manure into the fields. Men and women plant corn together, but the bulk of the subsequent hoeing and weeding of the cornfields is done by women. After the corn has been sown, various pulses and beans are planted along terrace walls, and, as the corn grows, millet and rice seedlings are started in irrigated beds.

When the monsoon rains begin in earnest and water is plentiful, rice is transplanted into irrigated fields by large labor groups, hired for a few days by wealthier landholders. After this, in mid- to late summer, the millet sprouts are transplanted from the seed beds to be intercropped amidst the ripening corn. This work is often done by the nang groups. Harvesting the corn and transplanting the millet overlap in what is a very intense agricultural period for all, compounded for some families by the weeding and general maintenance of irrigated rice fields. It is a trying time when a person must work as hard as possible-according to Jyomo, "saying to myself it didn't matter whether I could stand it or not, I kept on working in the fields." After more weeding and hoeing of the millet comes the rice harvest at the end of the monsoon, followed quickly by the other main harvest, of millet.

JYомо: It may have been hard sometimes. Sometimes in those friends' houses, well, someone else would scold and even beat me, and I'd cry. That's how I might have stayed, going around there.

After coming here, here, well, I had a lot of girlhood friends. I would go around with my father's younger sister, Puttili, who's now the lama's wife, married in Slidsprings. We'd go around together affectionately. And I'd go around with Middle Wife in our house. ${ }^{9}$ Sometimes we'd go around arguing the way anyone who lives together does-we lived in a single house then, you see.

We'd do the fieldwork for the house. Nowadays that's much easier: I don't have to go so far away to get to our fields anymore. Then, we had to go as far as the other side of the river upstream a ways, to the wet rice fields on the far slope of the river, ${ }^{10}$ and to the wet rice fields which Sweetriches's Mother now works, ${ }^{11}$ and to the lowest hamlet in Stupahill and the wet rice

8. See Holmberg (1989) for a more extensive discussion of the Tamang calendar.

9. Nhanu, who, as wife of the middle (grand)son, is called Middle Wife, Middle Mother, or Middle Mother-in-Law depending on her relation to the speaker.

10. These fields were inherited by her husband's middle younger brother (Nhanu's husband) when the household was divided, so she no longer has to work them.

11. These fields were given to Jyomo's eldest daughter, now known as Sweetriches's Mother, when she protested her proposed marriage into a poorer household in a neighboring village. Many such special arrangements mitigate against the general prohibition of daughters' inheritance of paternal lands. Indeed, there is some evidence that Tamang daughters once had sub- 
fields in the river basin below, ${ }^{12}$ and to the fields by that place called Red Swing, ${ }^{13}$ and there below the spring. . . . Before, when all the brothers were still together, we had to go work the fields in all those places.

Among the many delights of doing fieldwork with farmers was being privy to their knowledge of soil, water, seed, fertilizer, traction, sun exposure, and seasons. I was particularly moved by the intensity of their involvement with every square foot of their holdings. It is not surprising, I suppose, since terraces are built and maintained laboriously on little bits of land, scarcely wider than the bund walls that divide them are high. Land holdings were talked almost as if they had lives of their own. Every field and terrace had a name, and sometimes there were named parts even within a single field.

Some of this attention to minutiae undoubtedly arose from practical concerns about soil fertility or water availability or solar radiation, all of which could dramatically affect productivity in the thousands of mini-climes found in the holdings of a single household. Wheat grown at the base of Stupahill, for example, matured in three months and could be rotated with two rice crops each year, while it took a full year to produce a single crop of winter wheat at the top of the village. Fields whose angle gave them a few degrees better sun exposure were concomitantly more productive. Fields with sources of water, whether natural or irrigated, were agricultural gold.

People's involvement with the land went beyond these practical implications. Places where something dramatic had occurred were marked-where someone had fallen, or been attacked by a tiger, or where the cow had hung herself by falling out of a tree she had climbed to forage. Trees, rocks, cliffs, streams, pinnacles, caves, open flat spaces, dripping mossy spaces ... the land was so saturated with human histories that the landmarks themselves seemed to have biographies. One could trace not just past owners of a field but users and notable passers-through, in times of flood, earthquake, landslide, or drought. The land reverberated with stories I had never imagined.

Jyomo: There, then, the men would build the bunds in the irrigated fields; we [women], well, we would finish off the work, shaping the edges of the bunds and scraping them free of weeds. Nowadays, women have it easy. We'd work to finish off shaping and scraping the bunds. We mothers would go to the fields carrying the midday snack for however many fathers there were building the bunds in the irrigated fields. Then we had to spend the whole rest of the day shaping and weeding bunds. You know, you have to

stantial inheritance claims, now undermined by two hundred years of rule under high-caste Parbatiya law.

12. Both of these locales still belonged to Jyomo's husband, but shortly after this telling, an additional house was built down below for her son's senior wife. By eight years after this account, Jyomo's son's senior wife was living in her own establishment. When her son married, though, she moved back into another house in the main village.

13. Fields which also now belong to Middle Younger Brother and his (Nhanu's) household. 
scrape and weed all the bends and angles of a bund. As much as the fathers would build, we'd scrape and weed equally, working to scrape and weed all the crannies.

\section{Women's work and men's work}

The complementarity of men's and women's work was another bedrock of Tamang experience. The preceding passage from Jyomo is rich with indications of the interdependence of men and women. First of all, Jyomo uses the terms ama-mha, or "mothers," and apa-mha, or "fathers." There is no expression for female or male people except those inflected by kin relations: there are fathers and mothers, brothers and sisters, husbands and wives, but no generic men and women. In the spoken western Tamang dialect of the Stupahill region, the usual way of referring to men and women-as in "The men went fishing" or "I saw three women walking"-is "The fathers went fishing" and "I saw three mothers walking." In the region just to the north of Stupahill, meanwhile, the generic terms were mring and hrembo, "wife" and "husband"-still kin-embedded, but in marriage, not parenthood.

One of the trickiest questions about gender complementarities is whether they are symmetrical or hierarchical. It is easy in most cultures of gender difference to elicit attestations to the complementarity of male and female, where one is different from, and in some sense fills out, the other. It is a harder ethnographic task to determine whether this complementarity is one of balance-in which each party contributes as much and gains as much as the other-or whether one party either contributes or benefits substantially more than the other. Jyomo's account clearly argues for a gender parity among Tamang in field labor, both in its use of father/mother terms and in its insistence that mothers did every bit as much as fathers.

Jyомо: After working that much in the fields, and more, you'd think someone else ${ }^{14}$ would be content. Today's mothers, what do they have to do? But at that time, we would work scraping and weeding the faces of the bunds until they were done. And even if we did all that like that, do you think Grandfather showed us any affection? Grandfather would scold us. More than he would his own grandchildren, ${ }^{15}$ Grandfather would scold us a lot. And then, if we went to festivals, Grandfather would give us a real talking to. He'd say we didn't even do the household tasks quickly enough. He'd say we didn't make the fieldworkers work well enough. Everyone was working as hard as they could, if I do say so myself. He didn't trust us. Say you

14. It is not clear which someone else she means here-her husband, the fathers, "today's mothers"-but the rest of this paragraph suggests it might be Rich Grandfather.

15. That is, first of all, Jyomo's husband and his brothers. It could also include Nhanu, who was sometimes accused of being favored, although Jyomo claims in the following sentences an especially close relation with her. 
get tired yourself, don't others also get tired?! That's the story of fieldwork! [Laughter]

Saying, "You want to sit at ease, to loaf, but you haven't come here to sit around. Why don't you work faster?" he'd say. But others get tired too! You get tired yourself. I guess someone else never got tired. "The workers are doing enough!" he'd say. That's the kind of talking to he'd give us. That's the tale of fieldwork.

In that way, we worked; in that way, I stayed on here. I don't have a lot of girlfriends here. I'd go around with those two-with Puttili and Middle Wife. With those two, I'd go around a lot. I didn't go around lovingly with any other friends.

After the peripheral crops have been harvested and hay made from the stems and stalks comes the slack agricultural period of the year. This is when social life flourishes: most weddings, first haircuttings, and memorial death feasts are celebrated during this period. There is less farmwork to do, the food supplies are plentiful, and the weather is cool, dry, and clear. It is during this period of the year that women do most of their traveling to visit parents, brothers, sisters, and old friends. The sight of women walking between villages, carrying cloth bundles containing some foods and, more importantly, a wooden jug of alcohol to offer on their visits marks this as the time of greatest sociality for the Tamang.

\section{Herding and work with livestock}

Livestock, like crops, are vital to the Tamang household economy. A poor household might have only some chickens, or, at best, a few goats and a cow, not always milking. Richer households will have several water buffalo, bulls, cows, and lots of goats and chickens. In Stupahill the manure from all of these animals is composted to provide the main source of fertilizer for the fields. The meat of goats, chickens, and male water buffalo is highly valued, but they are butchered almost exclusively on religious or festival occasions. ${ }^{16}$ Bulls and oxen are kept as plow animals. Cows and female water buffalo provide milk, yogurt, butter, and buttermilk.

While land is owned almost exclusively by men, livestock constitute women's special wealth. Men may buy and own animals, but women specifically receive animals, along with household utensils and tools, from their parents as dzo-property. Women are particularly attentive to these animals, providing for most or all their needs, especially carrying water and fodder for them. For help with her animals, a woman will rely most on her own children. As both her herds and her children grow, then, a woman comes to oversee all the animals associated with her household.

16. Female water buffalo are not slaughtered; neither are cows, bulls, or oxen. 
In women's descriptions, their daily responsibilities are anchored by fieldwork and animal husbandry. Mhojyo said:

We worked together, the three of us sisters. We'd cut one load of fodder first thing in the morning, we'd cut that fodder, then, a little later at midday, after working in the morning field labor exchange groups, we'd go and cut another load of fodder. Every day, we'd milk the water buffalo, and churn the previous day's buttermilk, and after churning the buttermilk, we'd bring the fresh milk to a boil and set it aside to make tomorrow's buttermilk, then we'd cook our meal. We'd eat that, and then we'd go out to join the morning labor exchange groups.

Caring for animals is major labor. Chickens are (at least casually) watched in the day and penned at night, both to keep them out of the family food stores-such as any grains that might be drying outside-and to protect them from marauding birds of prey, jungle cats, jackals, and, on rare occasions, tigers or snow leopards. Every day, herds of goats, as well as various cattle and buffalo, are taken out to graze in nearby pastures or vacant fields-a task that usually falls to children. Milking cows and water buffalo are stabled in sheds near the house. Fodder must be cut and brought to them; they must be milked; their milk must be turned into the various other dairy products. Periodically, the sheds and shelters of all the animals must be cleaned and their manure shifted to compost piles and, ultimately, carried out to be worked into the fields.

The richest households have more animals than they can keep at the homestead and use separate herding stations. Others loan some of their livestock out to their poorer kin and neighbors in a variety of share-herding arrangements. Generally, the owners retain the right to sell or slaughter these animals, and keep whole or partial rights to any offspring. The household taking care of the animals generally gets to use the manure; in some cases, the caretakers also get rights to some or all the dairy products if the animal is milking, and may be able to keep a percentage of the offspring born under their care.

\section{Wage labor}

Trade and porterage are the most common jobs that take people out of their homes and frequently out of their villages. This work is particularly important to young adults, who are old enough to carry substantial loads but not yet burdened with full responsibility for a household. In the past, each Tamang household in this region had to send at least one person to Tibet to trade for salt once a year. Many households also had porterage obligations to the royal and allied families in Kathmandu. "All I did was go walking about on trading trips," said Hrisang of her youth, and Nhanu, as we have seen, de- 
scribed earning some money as a young woman carrying beams of construction timber to Kathmandu.

Today, young women and men still engage in trade, less with Tibet, but more commonly with Kathmandu and lowland Nepal. They might even go as far as Darjeeling and Assam in northeastern India or Himchal Pradesh, Jammu, and Kashmir in northwestern India. Other forms of wage labor known to local Tamang include porterage in the trekking industry, work on road crews, and positions in the Nepali, Indian, Singapore, or British military. ${ }^{17}$

\section{Domestic work}

In Tamang households, water must be carried, grain husked, food prepared, children cared for, clothes washed, firewood split and the fire tended, and the houses swept. In most of these daily tasks, the boundaries between house, field, and herd are not sharply drawn. Water is hauled in heavy copper jugs from sources that are rarely closer than a quarter mile away and usually up or down steep slopes. ${ }^{18}$ The water is as much, or more, for fruit and vegetable gardens or for the buffalo stabled near the house as it is for human use within.

The production of food grains, pulses, and some vegetables certainly begins in the fields, but there are many steps between field and meal that cloud the distinction between agricultural and domestic labor. Staple grains, for example, must be dried, threshed, and winnowed at the time of harvest, before storage. Then they must be dried again prior to husking, and re-winnowed before and after milling; only then can they be cooked. Hearth, house, porch, courtyard, stables, fields, pasture, and forest are interwoven in a complex productive enterprise in Tamang life. Such an endless round of work led Jyomo to comment, "It's a tale of the carrying of women, of the cooking of women."19

Cooking and childcare-perhaps the defining features of the domestic

17. Note, however, that Tamang were officially forbidden to seek employment in the military. Military service was, therefore, far less important to Tamang villages than it was to, say, Gurung or Limbu ones. Nonetheless, some Tamang did do military and especially police duty, sometimes by falsifying their identities. See DesChene (1991).

18. Since the time these accounts were recorded, the villagers of Stupahill, almost entirely without the aid of development agencies, have installed a rudimentary water system, bringing water taps into the central hamlets of the village. The benefits go well beyond reducing the daily labor of carrying water; there have been significant improvements in local hygiene as it is so much easier to wash things now. With the recent help of a small non-profit organization, Educate the Children (Ithaca, New York), almost every house has built an outhouse; even more remarkably, the outhouses are being used.

19. For a statistical analysis, based on time-allocation studies, of an eastern Tamang community see Acharya and Bennett (1981). 
sphere in western lives and minds-spill from Tamang houses to courtyards to fields. Neither preparing meals nor tending children are highly elaborated activities among the Tamang. Children, except for infants, largely care for themselves, although they are watched, in a general way, by all. Even infants, who are nursed and kept clean by their mothers, are often placed in cradle-baskets suspended from the porch rafters and left alone while their mothers go off to work. Most of the time, children wander in and out of houses, through courtyards, and around the village pretty much at will, in the company and care of older siblings and playmates. For most Tamang children, work and play, watching and helping others, and being watched and helped themselves are overlapping activities.

Numerous village scenes come to mind but are difficult to classify. A child with a smaller child strapped to her back was laughingly chasing a chicken round and round the yard, thereby keeping it away from a pile of drying grain, near which the children's mother sat weaving as something simmered on the fire. Was the child working, playing, caring for a younger sibling, or being cared for by her mother? And was the mother cooking, weaving, caring for children, or drying grains? If the children on the hillside with their families' goats are herding, who is watching the very young children in their midst, and who is watching the goats when they all get absorbed in their games? Even for the increasing numbers of Tamang children who are beginning to attend school, there are no sharp boundaries either between work and non-work or between their world and that of adults. Tamang children are integral members of their households; they do far more work than they cause.

Cooking, too, is only one among many household tasks; it must accommodate the other labors of household members. Whole extended families may linger over the evening meal, talking and relaxing until bed, but throughout most of the day, people eat hurriedly, in no particular order, whatever has been prepared, with whomever is around, and go off to their next task. Meals are only prepared twice a day, once in mid-morning and once again around sunset. Even full meals are simple and the same almost every day: rice with a pulse or vegetable curry for the larger landholders (or on special occasions), and corn and millet mush for everyone else.

Mush, the staple of the local diet, is made by adding flour-in Stupahill, usually a mixture of corn and millet flour-to boiling water and stirring it constantly, until it is about the consistency of soft clay. It is eaten lukewarm or cold with some sort of soupy accompaniment, with luck a pulse or vegetable. It is unquestionably hearty, and even good, but for most outsiders, it is an acquired taste. Tamang themselves talk with ambivalence about their mush (at least with me): they know that white rice is more valued in the larger Nepali world; they were often pleased that I found mush tasty and filling, especially since I was notorious for my inability to eat what were consid- 
ered respectable amounts of white rice. To my sensibilities, denigrating this mush in favor of white rice ultimately denigrates the reality of Tamang resourcefulness in the face of their poverty.

Around meals, then, the day is divided into two major work periods: one before the morning meal, and the other in the afternoon. At sunrise, and again in the mid-afternoon, people snack on leftovers, popped corn, roasted wheat berries, soybeans, or peanuts. As coffee breaks punctuate the western workday, these meals and snacks parse the Tamang day. The morning work is done after a hasty snack on rising, but before the main morning meal. When rotating cooperative labor groups meet to do only the morning work, the host household need provide no food for them. If workers are called together for a full day's work, however, host families are expected to provide a full morning meal and supply some beer to accompany mid-afternoon snacks. Those who assemble only for the afternoon work receive beer and snacks for their labors. Thus, meals are not prepared in every house every day but often eaten by workers wherever their labor takes them. Food and work are as firmly linked in the Tamang imagination as are food and family.

\section{Family: Clan, lineage, household, mhémé, and phépé}

The family consists of many groupings. First, there is the clan and lineage: all Tamang are born into the line of their fathers' fathers; they trace their descent in unbroken patrilines back to mythic clan founders. Patrilineage and patriclan membership are vital to both men and women. These largest conceptions of family regulate the widest circles of social exchange, especially marriage. No marriage can occur between members of the same lineage, clan, or brother clan. Tamang people imagine that clans were really once large patrilineages. Clans share mythic origin histories, but actual lineage ties cannot be traced among all clan members. The effective patrilineage is usually more localized, and genealogies are known.

Next, there is the extended patrilineal family. Even within a single locality, many patrilineages have very distinct, and sometimes hostile, sublineages. These sublineage groups typically consist of three or four generations of brothers and their sons. The households of these sublineage members cluster near the ancestral home of their shared apical patri-ancestor. This patri-ancestor is usually a grandfather, whose house is surrounded by the houses of his grown sons, in which their sons and sons' families live. The village of Stupahill had distinct hamlets, each housing identifiable sublineage groupings. Lots of informal visiting takes place in these hamlets. Children, especially, move between the houses of their adjacent patrilineal uncles with great ease. But even mature brothers, sisters, and close patrilineal cousins visit, relax, borrow, and intercede readily in each other's houses.

Households define families next. Tamang households aspire to being multigenerational, patrilineal, patrilocal families, which means that a man 
hopes to keep his sons living with him even after those sons are grown and married. From a woman's point of view, families and households look different. Except under rare circumstances, a woman will move to live in her husband's household and village after they marry. Tamang women need not move immediately after they marry, nor must they keep uninterrupted residence in their husband's home after marriage; they are always free to move back and forth between their natal home and their marital home. Home, then, for men, is the house and people of one's own natal patriline and patrilocal; the Tamang word dim can be used both for the building and its rightful residents. For women, however, there are ultimately two homes: the marital home, or dim, and their birth home, known as apa maiti, apa maiti ja, or phamyung.

Most homes contained more or less predictable family units. There were some exceptional households in Stupahill in which, for example, two poor widows lived together by themselves, and there was Mondzom, living with her two granddaughters, but, while not considered improper, neither were they the norm. The smallest Stupahill Tamang homes typically contained a nuclear family, often a younger couple and their small children. The largest households contained whole patrilineal segments, plus some. Thus, for example, the joint household in which Jyomo, Nhanu, and Purngi all lived at one time included Rich Grandfather, Mondzom, Grandfather's son and (until after her marriage) daughter, the son's wife and their unmarried daughters, also their three married sons and their wives-Jyomo, Nhanu, and Purngi, of course, but also Jyomo's co-wife-all their children, and, finally, occasional resident herders and supplementary day workers (see fig. 6). "You have to understand," said Nhanu of the joint household, "ours wasn't a small family there. Then, when we were all still living and eating together, we had to cook thirteen, fourteen-no, fifteen!-pint-measures of uncooked rice. And, if the whole extended family were all gathered together at one meal, we had to cook twenty pint-measures of rice!"

Tschirto originally came into Jyomo's household as a day worker. By the time she had married in, Grandfather was dead, as was his son; the three grandsons had divided their inheritance and split off into their separate households. During the partition of the grandparents' household, Jyomo and her husband were the first to build their own separate house. Nhanu, her husband, and their children continued to live with Mondzom in the old house for some years, during which the youngest brother and his wife, Purngi, lived with the oldest brother, but still mostly took care of the herding station. An additional house was later built for Purngi, her husband, and their children; then, finally, a separate house was built for Nhanu and hers, while Mondzom continued to live in the ancestral house. In the household Tschirto and Jyomo shared at the time of these tellings, then, lived Jyomo, her husband, their unmarried daughter, the dead co-wife's now-dead son's daughter, their surviving son and his wife-Tschirto-and their two young 


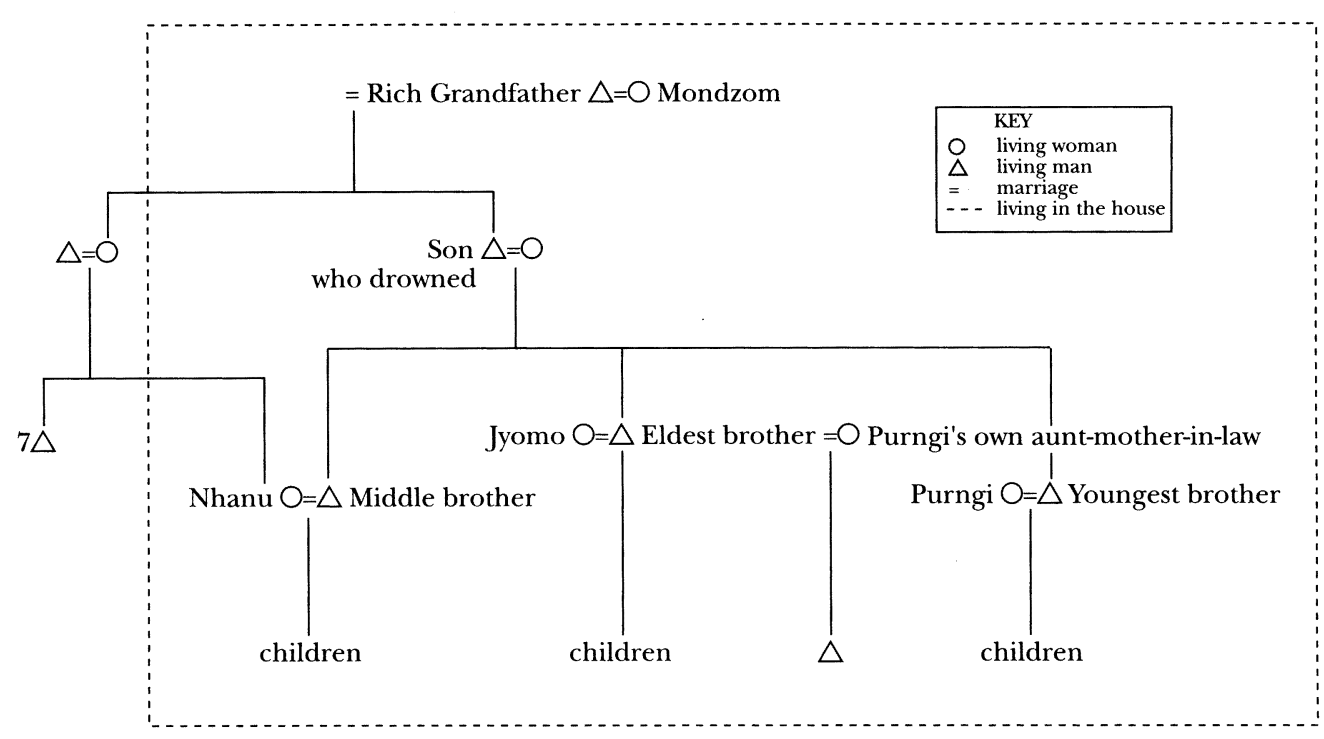

Fig. 6. Jyomo's extended household

children (see fig. 7). Occasional workers and we anthropologists also took up residence there.

Although it is dizzying sometimes to keep track of relationships as dense and those among the Tamang women of these accountings, it is important to visualize who lived in their households. Tamang households are defined simultaneously by the roof that covers them and the people who animate them. A Tamang dim, then, is a house in the sense of the House of Stuart, or, more anthropologically, the House of Lim (Wolf 1968). Most work and property (excepting, for instance, a woman's dzo-property) are managed jointly by the members of a household. Tamang people spend most of their time dealing with other members of their own household. Households act as a collectivity to offer hospitality and to make contributions to many ritual and social events.

Households are headed jointly by the seniormost man and seniormost woman: they are the dabo-damo, host-hostess, lord-lady, headman-headwoman of the house. Their authority theoretically extends over all those under their roof, but practice is more complicated. The best-documented practical complication in the anthropological literature is that, although brothers are supposed to be always united and filial, they are inevitably neither. Fathers age and sons replace them, but not often gracefully. First, they must split up the structure, endowment, and personnel of the house. The fracturing of the joint household-in both anthropological and Tamang stereotypes-is blamed on the daughters-in-law. "Oh," commented a man overhearing Phurko and Hrisang talk about life as co-daughters-in-law, "but it's so often a tale of one or the other sister- or daughter-in-law saying 'What did she get to eat?! It's be- 


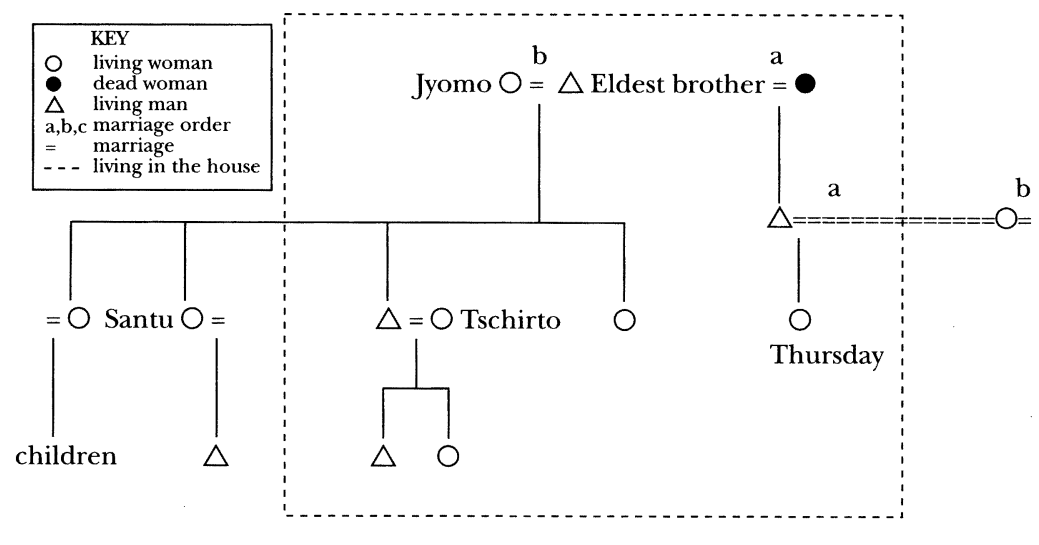

Fig. 7. Jyomo's household residents in 1977

cause she gets to eat what she wants that we don't get along anymore, isn't it?!'" Certainly, the women of the house are almost always implicated, but in ways I hope to show are more interesting than typically portrayed.

In Jyomo's case, for example, her husband had been married before, but his senior wife had refused to come to live with him, leading to his second marriage with Jyomo. Nevertheless, it seems that the senior wife had a strong pull on him, so that Jyomo's husband tried repeatedly to induce that first wife to join him. In the meantime, Jyomo, as she tells it, sustained his household through her diligent labors; she also bore his children.

Jyомо: [Loudly] Then ... that ... after my husband brought that senior wife down here, then, well, that husband of mine didn't show any consideration for me at all. After saying "Go away, you pumpkin-stomached despicable woman. Look what you have done!" My husband spoke with contempt. Whatever I did, he scolded me; we argued all the time. Even in the house itself, ${ }^{20}$ we argued that way. We still argue that way. That's how it's always been.

I was brought here in marriage after it was said that the first wife wouldn't stay long. She was from Old Brahmintown. ${ }^{21}$ I had had three daughters by this time-Sweetriches's Mother was almost all grown up by then.

[In Nepali] Only after my daughter was pretty grown up did he bring back that earlier wife. He called me a pumpkin-stomached blacksmith woman, that's what he called me.

[In Tamang again] That's what he said; and so we argued. In order to

20. That is, in front of everyone.

21. There is a widespread belief that marriages between Old Brahmintown and Stupahill residents don't generally work. See also Purngi's and Sukumaya's accounts. 
work those fields of his I had to go all over creation. I had to see to the animals. I got the fodder and the firewood. I did all that, but he never mentioned it. While saying, "With so many people in a single house, we should live peacefully," he would say that I let others do my share of the work. A shirker, me! I went around working all the time; everyone worked. But he would say I shirked my work and foisted it off on others. Everybody would go around working all the time. Everybody got to eat. Everybody went on that way. Whoever said that one person could do the work of ten? So even though he'd say that, I did my share of the work to the best of my ability and I didn't not eat my share of the food. ${ }^{22}$

[Loudly] Even I, though, well, those times I really cried a lot here, I did. And then I'd get scolded even more. Grandfather would scold a lot, he would. Because that kind of contempt was directed at me, my own heartand-mind would hurt.

[In Nepali] My feelings were hurt; I'd cry.

[In Tamang] I stayed on even though my suffering was as great as what you feel when your father and mother die. That's what became of me. Sometimes the sorrow I felt, I'd say it was more than the sorrow of my father's and mother's deaths, a lot more.

Myself, I have four birth-children: there were eight, but four died. I went around crying so when those children died. Myself, how I cried. That's been my own suffering. One son and three daughters of mine died. After they've gotten big, after they're gown, if they die then, you suffer a lot. [Pause]

Children-my own birth-children died. Father and Mother died. Younger Brother died. Younger Sister died. Whatever I had is gone. I'm all alone by myself. I have the four of my birth-children-those four children. Such bad fortune: I should die first myself; but myself, it seems like I've been left behind. How can I know that the same won't happen to those four? 23

To understand the complexity of relations in Jyomo's early and mid-married life, we must first understand the germinal Tamang family forms, the mhémé and phépé. A phépé is a father and his children; a mhémé is a mother and her children. Many of these smallest family units may live together under one roof. Each woman mothers her own circle of children. Her circle will overlap with that of her husband, but, if he has had more than one

22. Apparently, Jyomo wants to draw a connection between working in a house and being entitled to eat from the produce of that house, as linked obligation and right. But she is also alluding to the women's reputed practice of refusing to eat as a form of protest.

23. Sections omitted here include a history of the weaving and dyeing techniques found in Stupahill, a choppy question-and-answer exchange regarding Jyomo's first marriage, a description and history of women's jewelry worn in the region, and an account of a cholera epidemic in Stupahill. 
wife, will not be identical to his. Moreover, each of his brothers will father his own circle of children, which in turn will intersect with those of the brothers' wives.

Co-daughters-in-law, each of whom is brooding over her own separate clutch, often, it is said (by both anthropologists and Stupahill Tamang), find it hard to get along. Each seeks to secure preferential treatment for her own children and is envious of the others' attempts to do the same. Such a scenario posits that the women drive wedges between their husbands, who, as brothers, are supposed to be so unified they would never think of separating. All thoughtful people-anthropologists and Tamang alike-understand the patrilineally useful duplicity of such portrayals. In these women's narratives, however, we can see much more multifarious alliances.

KSM: [Changing the subject] Who among you reached this house first in marriage: you, or Middle Aunt-mother-in-law, ${ }^{24}$ or Youngest Aunt-motherin-law? ${ }^{25}$

JYOMO: First to arrive in this house?

KSM: Yes.

JYOмо: First, well, it seems they brought my co-wife-and-daughter-in-law from Old Brahmintown. After bringing her, after six or seven calendaryears, even after doing the wedding, she said she wouldn't stay. Then the middle wife had been brought and placed here; before me, Middle Wife had been brought and placed here first. I was only brought after the senior wife from Old Brahmintown said she wouldn't stay.

Here, again, I am reminded of the force behind these kin terms. Just as the term for mother-in-law (anyi) includes the idea of aunt, so is the term for cowife-and-daughter-in-law (tschamo) complex. Tamang traditionally allowed a man to take more than one wife; although this was not very common, and often involved two sisters, it was a way that a rich household could bring in more than one adult working woman. Because most young people lived in joint households, at least at the beginning of their married life, the more common and significant co-wives were actually the wives of different brothers. Whether the wives of the same brother or of different brothers, these young women were tschamo, daughters-in-law in the same house.

KSM: And after doing your wedding?

JYомо: After me, the youngest wife had been brought. After I arrived here, after there were two children here even-my firstborn daughter and Middle Wife's daughter. The one's Sunday's ${ }^{26}$ family circle and my firstborn daughter has now reached Slidsprings in marriage. She ${ }^{27}$ was

24. Nhanu.

25. Purngi.

26. Nhanu's (Middle Wife's) eldest daughter, named after the day of her birth.

27. Purngi. 
brought in the calendar-year when those two were born, in the cycle-year of the dog. She had been brought in the cycle-year of the dog. More than two of the twelve-year cycles have passed. That Speechless's Mother ${ }^{28}$ was brought in the cycle-year of the dog.

We two-Middle Wife and I-the two of us had daughter-children in the same year: Sunday, well ... mine, well, mine was born in the Nepali month Asoj; Sunday, in Poush. We both had daughters.

ksM: And how was it with your co-wives-and-daughters-in-law? Good? Or did you fight, or ...?

JYomo: Me?

KSM: Yes.

JYoмо: With them?

KSM: Yes.

JYOмо: I never spoke [harshly] with them. ${ }^{29}$ It was good enough: there were no fights; we didn't really argue, even if we did, it wasn't serious. I never said anything [harsh] to them, to my co-wives-and-daughters-in-law. I didn't even speak harshly to the co-wife-and-daughter-in-law of our mutual husband. I didn't speak harshly with the co-wife-and-daughter-in-law of Husband's Younger Brother. Myself, I never really said anything harsh; the others never said anything harsh either.

Why go around speaking harshly? What's there to say about the times when things were ugly? After doing whatever you will, you still have to eat; whatever others do, too, they still have to eat. If the work doesn't get done, no one eats. Myself, I worked as well as I could. Others might have spoken harshly; not I. Even if others spoke harshly, I wasn't one to argue. Others would argue.

Ksm: And, then, after you came here, were the brothers split up yet? Did that happen before you came here?

JYOмо: The splitting up, ${ }^{30}$ well . . . it was only after my lastborn son was all done and born. Four of mine had fully happened while the whole family was still all together in that one place. They only split up after my lastborn son was born.

KSM: And in that time what all happened?

JYOMO: In the time of coming out? 31

KSM: Yes.

28. Purngi, as she is called by the nickname of her oldest surviving child. Note the many different ways of referring to her, even in this brief exchange.

29. The boundary between speaking and speaking harshly is difficult to document in Tamang language; depending on the context, the same verb-pangba-can mean either "to speak" or "to speak harshly."

3o. Referring to the division of the extended patrilocal homestead into the separate households of the three brothers. For more about this division, see the chapter based on Purngi's account.

31. Another common way to refer to the separation of brothers from each other and from their shared father's house. 
Jyомо: In the time they were coming out from the joint homestead, Grandfather, well, Grandfather and his grandson ${ }^{32}$ didn't get along and, after saying, well, "Come out! Go stay in your separate houses," Grandfather said. "There are too many in the whole family. None of you get along. What else can be done?" he said, said Grandfather.

And so, after that, "Come out and get out of here!" he'd say. Only after building this house did we come out.

KSM: First this house was built?

Jyомо: No. The main house was down below there. Then, after finishing this house, we had moved. And so saying, we moved, you'd say. Elder Wife died in the month of Bhadau; the death feast ${ }^{33}$ was done in the month of Magh, in Poush and Magh. From the beginning of the month of Phalgun, we built this house. Phalgun had just begun and from that beginning, by the middle of the month of Baisakh, we had finished making the house and so that's how it happened that we moved in Baisakh. My co-daughterin-law-and-wife died and dying, only after she died, had we come out of the joint homestead. ${ }^{34}$

When we co-daughters-in-law-and-wives were all together, when the whole family was together ... [Pause]

They, well, the others, well . . because Middle Wife was one of those people who has received a lot of her own dzo-property from others, ${ }^{35}$ she would speak contemptuously of us and ...

When they were all together Elder Co-wife-and-daughter-in-law died and only then, well, after buying our house, ${ }^{36}$ Grandfather said, "Divide and come out!"

\section{A woman's relations in her husband's home}

"Divide and come out!" is the ultimate paternal challenge in Stupahill. It means "Divide your inheritance and come out of the extended household to set up your own." It is an inevitable stage in household development as families grow too large and interests too diverse. But it is rarely a happy occasion.

Ideally, for Stupahill Tamang, the moment when brothers are well enough established to live comfortably on their own will coincide with their father's

32. That is, Jyomo's husband.

33. The death feast (or gral) is probably the single most important social and religious observance among Tamang in the region. Extended kin come from miles around to take part in a feast and ritual intended as much to reaffirm relations among the living as to ensure a desirable rebirth for the deceased. See Holmberg (1989).

34. Compare this mention of the elder co-wife's death to the version in Purngi's chapter.

35. Nhanu, as we saw in her account, said she did not receive much dzo-property, but others assumed she had received things from Rich Grandfather, who was not only her senior fatherin-law but also her own real grandfather. See also Purngi's account of the splitting up of the brothers.

36. Presumably buying the materials and fittings for the house, since they actually built it. 
death. After the father dies, each of the sons is entitled to inherit an equal share in the estate. Property is publicly divided so that any counterclaims can be aired and answered. Daughters are not entitled to an inherited share, but any property that has been set aside as their own dzo must, as we saw in Nhanu's tale, be untouched by brothers.

If, as if often the case, the household becomes too unwieldy before the seniormost generation dies, brothers can call for partition. The timing of the division is essential: all the brothers must be capable of administering their own shares; all the resultant households must be self-sufficient. Often, however, the differences in brothers' ages is as great as the differences that drive them to partition, so, not infrequently, brothers peel off from the parental estate sequentially. The formal public witnessing of the division will still occur, but some of the brothers may continue to live jointly.

Commonly, the parents hold some portion of the estate in personal reserve, depositing it finally with the son who takes on their eldercare and funereal obligations. The ideology of solidarity among patrilineal brothers makes partition an unsavory moment in household life. Even though tensions among brothers and between father and sons are invariably high at these times, their disputes are often blamed on nonpatrilineal members of the household, especially the brothers' wives-the tschamo or co-daughtersin-law. With the additional complexities of both plural and cross-cousin marriage, the possibilities for domestic intrigue are legion.

JYомо: And so saying, Grandson ${ }^{37}$ said, "What? Would you tell me to go and barricade off part of someone else's house and live there? I'll only come out after my own house is built."

And so saying, Grandson was told by Grandfather, "Come out, you fourpint scarface! ${ }^{38}$ Living together in one place, you don't do any of the work. You don't do anything," said Grandfather and after arguing like that, that was how harshly Grandfather spoke. [Pause]

KSM: Like that.

And what had been your relation to that father of yours? ${ }^{39}$ Before you were married, what had been your relation?

Jyoмо: With me?

KSM: Yes.

TULARAM: In the time before the wedding was done?

KSM: Before the wedding, yes.

Jyomo: Before the wedding was done?

37. Jyomo's own husband.

38. A double insult: four-pint refers to his capacity to consume four pints (mana) of uncooked rice at a single sitting without apparently having worked enough to deserve so much; scarface refers to the pockmarks left by smallpox, which regularly visited Stupahill in epidemics until the worldwide UNICEF inoculation campaign eradicated it.

39. That is, Jyomo's husband. 
KSM: Yes.

JYOмо: Nobody really knew anything about it. It's not that there was anything really to it. I was his grandmother they say, or that's what I'd heard. I'd heard it said that I was grandmother to him. ${ }^{40}$

TULARAM: [Chuckling] Oh, so you're not our aunt-mother-in-law, after all, but. ...

You must mean you were a paternal younger aunt. I mean, you couldn't have been grandmother. You must have been some sort of younger father's wife....

JYомо: No. They say I was grandmother. Grandfather would then have been a sister's husband to me, it seems. ... Even more strange, I would have been a potential wife to Grandfather, it's said. His father, well, to his father, I would have been a younger uncle's wife, it seems. Or so it was said, I've heard. ${ }^{41}$

\section{Parents-in-law}

In order to unravel the various relations in Jyomo's marital household, there are some additional kin terms that must be learned: kén and syumé mean, respectively, "father-in-law" and "mother-in-law." That is, they mean "the parent of my spouse"; but in Tamang marriage, where brothers' and sisters' children marry in cross-cousin marriage, a father-in-law should also be an uncle and a mother-in-law an aunt. The terms anyi and asyang refer, respectively, to "aunt-and-mother-in-law" and "uncle-and-father-in-law." Kén and syumé were used far less frequently than anyi and asyang, and could be used only to refer to someone, not to address him or her. To refer to one's parents-in-law in this way stripped them of the additional affectionate connotations of aunt and uncle. In Jyomo's discussion here, she refers to her parents-in-law almost exclusively as kén and syumé, signaling reserve, distance, and even cruelty.

KSM: Were things good, then, with your father- and mother-in-law? Jyomo: Here, you mean?

KSM: Yes.

JYOMO: My father-in-law, I never came to know. . . . Before I arrived here in marriage, he'd been carried away by the river, it's said. I only knew my mother-in-law; but my father-in-law, I never even saw.

After bringing my co-wife-and-daughter-in-law in here, after it was said she wouldn't stay here, and after father-in-law was said to have been carried off by the river, and it's said that even the middle wife wouldn't stay here to carry the snacks to the fieldworkers. Neither would the wife from Old

40. Marrying one's grandmother would be considered very strange; if she had not been so very distant a classificatory grandmother this would have been an unacceptable match.

41. One cassette tape ended here; a new one was inserted and I began it with the next question. 
Brahmintown. My co-wife-and-daughter-in-law wouldn't stay here, they say. So it's said that because they couldn't find anyone to carry the snacks down to the fieldworkers in the irrigated fields, that, so saying, Grandmother here, well, sending someone else to bring me here, in that way I was brought here. Or, more to the point, "After seducing and coaxing her, bring someone back here," Grandmother said, and so saying, that's what seems to have happened to me. I knew nothing about it of course.

TULARAM: And what was the trail of kinship relations along which you were brought here, Aunt-mother-in-law?

\section{Husbands}

Children and co-daughters-in-law are not a Tamang woman's only potential allies in her marital home. Tamang husbands and wives have highly varied relations. Some are very close. In elopements, which account for most marriages whether they follow long courtships or not, the couple knows one another. Often, there are traceable kin paths (as Tamang call them) between husband and wife, including some rather irregular ones. Mhojyo's future husband, for example, had been her classificatory son or younger brother before marriage, establishing a history of casual relations between them, as she described: "Yes, well, at that time, I was his mother's younger sister and he was my son or little brother. Then, well, we'd each go out to herd our family's cows and goats, and, if we ran into each other, that one's ${ }^{42}$ father would call me mother's younger sister. I, well, that meant that I could call him by name. I could take his name and call out to him, 'Hey, you! So-and-so,' I'd say calling out her father's ${ }^{43}$ name, just like that! ${ }^{44}$ Then he'd say, 'What is it, Mother's Younger Sister?' And I'd go on calling him by name . . ."-a liberty granted only to older intimates or superiors.

As we have seen, too, Jyomo had been grandmother to her husband. Women who married men with whom they had kin ties-ties perhaps even conferring to them some seniority or respect-found themselves in enviable positions, as we have already seen described by Nhanu.

JYomo: Oh, that one, the one who's dead now, from down below the irrigation channel, the one that they called Shorty's Father, that was the one who did it, they say. I don't know; I hadn't seen him; I don't remember anything about it. That was the one, though, that so-called Elder Brother. This

42. Indicating her daughter.

43. Meaning her daughter's father, Mhojyo's husband.

44. That she would call out his name is, of course, surprising because Tamang do not use personal names, but instead address people by kinship terms, nicknames, or the names of their children. Note that, although she once called him by name, Mhojyo here avoids even passing reference to what that name might be. 
was the elder brother whose wife was, you know, the older sister of the younger carpenter from Gods' Pasturage.

TULARAM: Ah, ah ...

JYomo: It seems it was him and his wife, the one called Shorty's Mother. She had come up here from down there in Gods' Pasturage to up here in someone else's father-in-law-and-brother-in-law's place. He was married to Gods' Pasturage's younger carpenter's older sister and it seems they said my own mother was then his elder mother-in-law.

Those were the ones who went between up here and down there in Gods' Pasturage. Those were the ones who knew, and knowing, Grandmother here said, when he was going down there, "I can't find anyone to carry snacks for the fieldworkers. My old man's two grandson's weddings have both been done, but even with two daughters-in-law, because I still can't find a single person to carry snacks to the fieldworkers, if whenever you are down there, there's someone suitable, coax and bring her back," she said and so he brought me back, they say. My so-called elder brother, the one they called Shorty's Father. Shorty's Father and that younger carpenter's elder sister from down below herself-those were the ones.

After coming down, it seems they had spoken to Mother. I might tell all this now, but I didn't know then. "If you go it will only make things even with those Firestone people. Since those Firestone people didn't care for you, it will only even things up with those Firestone people if you go. Go!" said Elder Brother. Speaking like that, after he'd gone on speaking like that, well, I went and came up here.

Listening to accounts as rich in kin and personal relations as these was a wonder, but also bewildering at times. It is striking that women have so many ties, yet, too often, so few who seem to care. In her natal home, a woman has much the same array of ties as her brothers. Above all, she has grandparents, parents, brothers (including classificatory patrilineal cousin-brothers), and sisters (including classificatory patrilineal cousin-sisters). She also has girlhood friends. These special friends, as we have seen, might be clansisters or they might be women of more or less her own age married into her natal community-her brothers' wives, for example. These are the friends with whom she exchanges nicknames, works in exchange labor groups, and, above all, with whom she sings and dances.

Women try to reestablish as many of their natal relations as they can in their marital village. Clansisterhood and girlhood friendship are pivotal. A woman who is unhappy in her husband's house may find her only comfort in the company of girlfriends, as Jyomo did when she lived with her first husband. To marry, as Sukumaya did, where no woman of her clan had ever married is by definition a hardship; if there had been clansisters where she married, "then there would have been friends." Many of the women told in these 
narratives of following another kinswoman in marriage. Phurko, for example, went in marriage to the same house as her close aunt, the one to marry the father, the other to marry the son.

The milieu in which a married woman most needs friends, of course, is her husband's household. In some other parts of Nepal and the world, a bride arrives as a stranger into her husband's house. Such brides are at a considerable disadvantage. Tamang brides typically have more leverage in their marital homes.

JYOMO: But before that, well, I hadn't known anything, not even a trace. I didn't know the person who brought me here. I didn't know anything: they said his ${ }^{45}$ face was thus-and-so; they said there was thus-and-such a person in such-and-such a place. I knew nothing: no trace, no knowledge. ${ }^{46}$

He was still a child at the time I arrived here in marriage. His hair was all over the place, hanging down in pigtails and ringlets. He was one of those with uncut hair growing out every which way. He was littler than I was; he was five calendar-years younger. He was still little in the calendar-year I came up here. [Pause]

Of these fourteen women, at least Nhanu, Mhojyo, Tschirto, and Purngi were somewhat older than their husbands. ${ }^{47}$ At least some of the women in each generation, too, had married men of their own choosing, whether in consultation with their parents or through elopement. In cases such as these, the relationship that developed between wives and their husbands had the potential to be very open and affectionate. Other marriages were clearly less happy. Jyomo's description of her first marriage, in the village of Firestone, as a very young girl to a much older man is bitter indeed. Not only was she unhappy throughout the marriage but the anger and resentment carried through the entire divorce.

KSM: And so, did you have a son first or a daughter?

JYOMO: First there was my firstborn daughter.

KsM: She was the first.

JYOмо: Yes. Only after I had two daughters, then came the son of the boarcycle-year who died. That son died, you see, and so ...

кSM: When he was little?

JYомо: Yes. When with my spouse we were all living together in his parents' house, after two daughters and one son had been made, that only son died. The daughter, after the firstborn daughter that I still have today,

45. Her husband's.

46. Here, Jyomo juxtaposes the most modern of phrases for total ignorance ( no trace, from the Hindi and Nepali for "sign" or "marker") with a second phrase drawn from Tamang mythic language describing a state before knowledge came into existence.

47. See table in Sukumaya's chapter showing the relative ages of husbands and wives in Stupahill. 
there had been another daughter who died. Only after the first son died, only then came Ngyhéma Karma, ${ }^{48}$ the son I have today.

KSM: It's been hard for you.

Jyомо: Very hard. I cried. Both after those children died, and after my spouse spoke harshly, I cried. Husband would speak harshly and I cried. After coming here to stay, I was struck by crying a lot. Someone else-my spouse-said foul things to me. He'd speak to me that way daily. Daily, someone else would scold. Lots of my children would die; someone else would speak harshly. I've been struck by so much hardship.

In this short speech, Jyomo uses three different referents for her husband, each charting different contours to their marriage. First, she uses jyan, a Nepali loanword that, as she uses it here, means "spouse," but is also occasionally used by Tamang speakers to refer to "family." Then she calls him hrembo, which is a classical Tamang word for "husband-man." Next comes hro, the colloquial Tamang expression meaning "someone else." And finally she repeats jyan (spouse/family). Jyan might be understood to emphasize their shared family relation, but it is also a slightly formal expression, giving a veneer of Nepali-derived cosmopolitanism to their relation. Hrembo unequivocally acknowledges the official marital relation she has with him and connotes some degree of traditional authority; it is the term most likely to be heard in mythic accounts of saints and heroes. The third term, hro, is very common among younger women; it conveys the idea that one's husband is a stranger, not someone to whom one is close. It is striking, in Jyomo's account of her children's births and deaths, that she never once refers to her husband in the most common form-as the father of her children, in general, or as the father of her eldest child, specifically.

KSM: If so many of your children died, why? What had someone else spoken so harshly for?

Jуомо: Someone else would speak harshly; our children would die and die, so that it seemed that there wouldn't be any left. What? Why? Someone else would speak harshly and crying thoughts would well up. My own heart-and-mind would hurt. Someone else would speak harshly and... [Pause]

These four died and, after four died, only four were left. [Pause]

When we all lived together in his parents' house, he would speak harshly a lot. [Pause $]^{49}$

48. A rare reference to a now-grown son by his given personal name, rather than his nickname or his paternal teknonym.

49. Here I have omitted accounts of Jyomo's divorce negotiations and first marital situation, her second husband's terms in jail, their children's marriages, Tamang marriage customs, and the customs pertaining to a woman's remarriage. She also spoke about auspicious days for doing various kinds of work, such as weaving and beer-making, and gave an account of the making of ritual friends. 
For better or worse, then, Tamang women do not marry into the houses of strangers: in some thirty-six percent of the cases, Tamang women marry the child of someone they call either Father's Sister or Mother's Brother. And, in all cases, parents-in-law become classificatory aunts and uncles after the marriage. Because of the structure of and distribution of authority in Tamang extended households, a woman's marital happiness will be colored as much by her relationship with her parents-in-law as with her husband. A woman will most readily forge new alliances where her mother-in-law is also an affectionate aunt, and perhaps her clansister, and her father-in-law is a doting uncle.

A similar logic can be outlined for each of the likely members of her new household. A husband's sisters might be themselves married into the house, hamlet, or clan of the bride. They might have been coworkers in exchange labor groups or girlhood friends with whom a bride went singing and dancing. Along with co-wives and co-daughters-in-law, a husband's sisters are likely to be the women closest in age and experience to the bride herself.

\section{Co-wives and co-daughters-in-law}

Last but not least, a new wife forms relationships with her co-wives. The Tamang term tschamo, as we have seen, does not differentiate between women who are co-daughters-in-law (wives of brothers) and those who are co-wives of the same man, so it is hard in much of the women's talk to know which they are talking about. Throughout the narratives, the relation of cowives-and-daughters-in-law is important, but there is no simple way of characterizing it. When it overlaps with co-sisterhood, girlhood friendship, or companionship in nang work groups, then, clearly, the relation can be very strong and warm. Even if it is primarily a relation forged in a shared dependent position in the marital household, as co-daughters-in-law, women may develop rich connections. Conversely, the relations among in-married women can be strained by rivalries-whether over a shared husband or children's rights—so the pressures against becoming too solitary are also quite powerful.

Some co-wives-and-daughters-in-law appear more or less to have avoided one another. Apparently, this is generally regarded as proper conduct in a less-than-desirable situation. Without exception all fourteen women of these narratives claimed at least a silent truce. In other cases, especially when there were previous ties among tschamo, they got along quite well. Thus, Hrisang got along well with her husband's elder brother's wife, who was also her own father's youngest brother's daughter. And Purngi felt very close to her husband's eldest brother's first wife (that is, Jyomo's co-wife) because she was Purngi's own father's sister.

In their daily lives, then, both before and after marriage, the women describe many cross-cutting relationships. Some of these relations are mediated 
through the dominant men in their lives, but many are not. Women are connected as clansisters, girlhood friends, aunts, creditors, heirs, and coworkers. The complexity of the semi-independent society of Tamang women is staggering.

\section{The work left for Jyomo to do}

ksm: And now. Above all, first, in your heart-and-mind, what do you think of?

TULARAM: Aunt-mother-in-law's hopes. Like hopes, in your heart-andmind, what do you recall now? Do you think: "What will happen to me? Will I be alright?" Or, what?

JYOMO: What do I recall?

TULARAM: Even if you were to die, to have a contented heart-and-mind, to be content ...

ksM: Sons' and daughters' weddings are done. And you have grandsons and granddaughters. In your heart-and-mind, what have you found?

Jyomo: If one's own dying era arises now, one must die-that's one thing. Now, well, even if I were to die now, there's only my one lastborn daughter who might be destroyed, 50 if I were to die now.

My son, what can I say of him? He's another's; he's all grown now. Two of my daughters, what can I say about them? They are married and sent off.

It's like the proverb: "To reserve the foddergrass for another, that's the work of the muzzle. ${ }^{51}$ If you die before your time, the tale of remembering yourself is yours alone; the rest is reserved for others. " 52

Grandsons and granddaughters, what can I say of them? As long as they have their own father and mother, their father and mother will take care of them. [Pause]

KsM: And, now, you've even been to Yembur.

Jyомо: What's that? To Yembur?

KSM: And your lastborn daughter, when will you do her wedding?

JYOMO: When?

KSM: Yes.

JYомо: We'll do it for that one. But some other time.

That one says she won't do it. But she's just a child, what? [Pause]

What else do I recall? What else do I think about? I'd say nothing else has arisen in my heart-and-mind. Well ...

5o. That is, hurt by her death, but the word used is stronger: "ruined," "destroyed," "spoiled."

$5^{1}$. A muzzle was used, as it was explained here to me, to keep the oxen from eating the straw as they are circled round and round a pole on the threshing floor.

$5^{2}$. That is, just as the muzzled ox cannot eat someone else's fodder grass, no one else can know or remember what has happened in one's life. 
"Thus the ox is muzzled according to someone else's say-so."53

"If only I found this, if only I found that thing, if only I found this or another thing to eat. If only I could find things to eat or those other things. ..." That's not what I think about. "If only I could have other things to eat. ..." I don't think about that.

What's the matter with me? I don't think about finding good, sweet things to eat like others do. Or about nice things to wear.

Only one thing: "Will this work or that work not get done? What work needs to be done?" That's the only thing I think about.

The only thing I think about is that if I die soon, it will destroy only my one lastborn daughter. That's the only tale in my heart-and-mind. I don't think about anything else in my heart-and-mind.

As for my sons and daughters: whatever will be will be. As for my son: even my son is someone else's oblation. ${ }^{54}$ Whatever happens, happens to them themselves. ${ }^{55}$ I might say, there's only the one I still think about sending off in marriage. Then, let whatever will happen, happen. Even if I die myself. . . . It's like "Gang Jyung Bomo Hwai."56 [Pause]

Ha-ri-lo! [Drink?] ${ }^{57}$ the very water of Lhasa.

Ha-ri-lo! The whole of the resounding monument. ${ }^{58}$

Ha-ri-lo! The whole of the resounding monument.

Ha-ri-lo! [Drink?] the very water of Lhasa.

53. Another proverb, which might also be translated: "So the ox ever wears the muzzle of what someone else says."

54. A very unusual and poignant turn of phrase since it distances Jyomo doubly from her only son: she refers to him as an oblation, an offering to someone else or some other divinity, and not even her own but someone else's oblation.

55. Hotti mupaa hro-ta-no tapaa. "Whatever might happen will/might happen to someone else $[-n o=$ a marker of emphasis], i.e., her children's futures are no longer hers to make or break.

56 . The more usual name for this cultural heroine is Gangjyungmo; here, her name is teased apart into Gang Jyung Bomo, so that bomo, meaning "woman" or "daughter," is emphasized. She is among the great jyomo, or women religious figures, of Tamang myth and song. She is credited with having built Khasyor (better known as Boudha), the great stupa and Buddhist pilgrimage site in the Kathmandu valley. She is described as a woman who suffered greatlylosing children, wealth, and husband-only to rise above her hardships and become wealthy once again. She applied her wealth with newfound spiritual wisdom to building the monument and thereby attained her own liberation. The song here has a double significance: it is the song of Jyomo's namesake and it is about neglect, death, and the ultimate victory of virtue. Jyomo did not sing this song in her original telling, but she did refer to it and approved of the full inclusion here.

57. The idea of drinking was implicit in everyone's understanding of these phrases but somewhat ambiguously so.

$5^{8}$. In some of these translations, it is hard to pull a single syntactic meaning out of the much more metaphoric, even metonymic, juxtaposition of images. Here, in Tamang, the phrase is chhyurten sangb-oi hri-la: the first word, chhyurten, denotes a Buddhist stupa (here, the monument known as Boudha in the Kathmandu valley); the second word, sangb-oi, means "resounded" or "came into noisy being"; and the third word, hri-la, is a common phrase either terminating invocations and intended to send them heavenward or an honorific meaning the whole of a creation. 
Ha-ri-lo! [Drink?] the water as it goes downhill.

Ha-ri-lo! The whole of the resounding monument. Ha-ri-lo! The whole of the resounding monument. Ha-ri-lo! Daughter, daughter of divinity.

Ha-ri-lo! Daughter, Gang Jyung Bomo.

Ha-ri-lo! The whole of the resounding monument. Ha-ri-lo! The whole of the resounding monument. Ha-ri-lo! Daughter, daughter of divinity.

Ha-ri-lo! Daughter, Den Jyung Bomo.

$H a-r i-l o$ ! The whole of the resounding monument. Ha-ri-lo! The whole of the resounding monument. Ha-ri-lo! Daughter, daughter of divinity.

Ha-ri-lo! A daughter's body suits you. ${ }^{59}$

Ha-ri-lo! There are silken clothes.

Ha-ri-lo! There are [another desirable kind of] clothes.

Ha-ri-lo! There are [another desirable kind of] clothes.

Ha-ri-lo! Daughter, Gang Jyung Bomo.

Ha-ri-lo! Daughter, daughter of divinity.

Ha-ri-lo! A daughter's body suits you.

Ha-ri-lo! Flower of the butter lamp offering for the dead.

Ha-ri-lo! The whole of the resounding monument.

Ha-ri-lo! The whole of the resounding monument.

Ha-ri-lo! Daughter, Gang Jyung Bomo.

Ha-ri-lo! Wandered around in all the countries of the world.

Ha-ri-lo! Found suffering of all kinds.

$\mathrm{Ha-ri-lo!}$ The whole of the resounding monument.

Ha-ri-lo! The whole of the resounding monument.

Ha-ri-lo! Daughter, Gang Jyung Bomo.

Ha-ri-lo! Wandered around in the Kathmandu valley.

Ha-ri-lo! Wandered around in the Kathmandu valley.

Ha-ri-lo! Didn't have even the littlest bit of money.

Ha-ri-lo! The whole of the resounding monument.

Ha-ri-lo! The whole of the resounding monument.

Ha-ri-lo! Daughter, Gang Jyung Bomo.

Ha-ri-lo! Wandered around in the Kathmandu valley.

Ha-ri-lo! Stayed at Syingmen ${ }^{60}$ Khasyor. ${ }^{61}$

Ha-ri-lo! After making offerings of butter lamps.

Ha-ri-lo! After making offerings of butter lamps.

Ha-ri-lo! Lit her own death butter lamps.

Ha-ri-lo! The whole of the resounding monument.

Ha-ri-lo! The whole of the resounding monument.

Ha-ri-lo! Daughter, Gang Jyung Bomo.

Ha-ri-lo! Lit her own death butter lamps.

Ha-ri-lo! Saw rebirth as a daughter.

59. Meaning more or less "a woman's body," but the term bomo emphasizes her corporeality as a daughter or sister more than that as a wife or mother (March 1998).

6o. The local Tamang name for Swayambhu, one of the two largest Buddhist stupas in the Kathmandu valley.

61. The other of those two great stupas, known more commonly as Boudha. 
Ha-ri-lo! The daughter of a Chinese king.

Ha-ri-lo! Daughter withered and died.

Ha-ri-lo! The whole of the resounding monument.

Ha-ri-lo! The whole of the resounding monument.

Jуомо:62 Hardship, well how can one even speak of it now? My hardship, even more so, more in the house of those Firestone people, then even more here. In Father's and Mother's house, I was carefree. If once you go stay with someone else's own father and mother, it's never again carefree. No matter how long it lasts, you know, you're not wise when you're young. ${ }^{63}$ Then as soon as you're grown up a little, you suddenly become a person living in someone else's house. Where's the freedom from cares?

[The water buffalo bellows more loudly than ever; Jyomo speaks quietly.] If only someone would give it a little fodder. Where has everyone gone?

KSM: Before, did people used to get married younger than they do today? Jуомо: You mean me?

KSM: No. Everybody.

JYOMO: Everybody?

кsM: Yes.

JYOмO: Before? Everybody younger than whom?

KSM: When they were younger?

JYOMO: Oh. Sure. Everybody married young.

TULARAM: She means, long ago, did they do the weddings for people when they were children, or today do people do weddings in childhood, people of today, that is?

JYOMO: Like nowadays, in the times I can't recall, only when others were a little big did they do the weddings, it's said. But when we two were only people not even as big as my lastborn daughter, we were carried off in marriage-me and that one from down below, who's the twin's wife. She and I, only we two were carried off when small. Others, well, only when bigger.

[Switching to Nepali, undoubtedly for my benefit, since I'd had trouble getting my question across] Only after they were big, did they do weddings. We two, well, we were only as small as my lastborn daughter. Small, we were maybe only that small....

TULARAM: [In Tamang again] In Firestone, had they been your unclefather-in-law? 64

62. The following sections have been omitted here: a lament about the fact that all her dzoproperty has (she says) been used up, her plans for giving property to her daughters, and a bit on weaving designs. She also discusses her parents and their deaths, and contrasts the joy of an unmarried daughter living with her parents and the hardship of living with "someone else."

63. Literally, "wisdom never arises in one's young childhood."

64. Asking whether her in-laws in Firestone had been any kind of kin to her before the marriage. 
JYoмо: Who? I don't have any trace of either uncle-father-in-law or auntmother-in-law there. It was that brother-in-law from long ago: it was that brother-in-law who made the arrangements to give and had given me away, it seems. There was no kinship relation to the Firestone people. There was no gotra. ${ }^{65}$ I didn't know them.

Even in marrying here, too, I hadn't known anything. Others did it just like that that time, too. I was lured into it and given and brought up here. That is, that old woman spoke even more alluringly. Whoever it might have been then, after speaking to me that way, that was the tale they came up here telling. There wasn't even a distant kin relation with anyone at all.

[Softly] I never even ever saw the Firestone people before the marriage. I never went there either before, when I was a child. [Pause]

The terms used here indicate that Jyomo was coaxed into marriage by talk and promises, although not necessarily the seductive wheedling of the groom himself. Women often recount the persuasion of other kin and friends, regardless of what they knew or felt about the future husband and his family. Sometimes this appears primarily to be a device of narrative modesty. Conjugal affection is only spoken about obliquely; courtship is highly charged in the abstract and in song, but to describe specifics and attribute affection directly would be highly embarrassing. It is equally clear, however, that Tamang marriage is a matter of concern to many more than just the couple. Cross cousins, siblings, parents, already out-married friends, and kin are all certain to have interests in a woman's proposed marriage alliance. It is appropriate, then, for Jyomo to describe her marriage as the result of others' desires, even though she undoubtedly had reasons to want out of her first marriage and was, by the time of the second, grown up enough to know how to evaluate marital prospects quite well herself.

JYomo: Sometimes, even in the middle of the night, when he would speak harshly to me, well, even though it was the middle of the night, I'd cry, and crying, come down home. In that way, crying. Someone else would speak so harshly, you see. I was in such distress. Some days ... oh, but what's there to be remembered?

I came down home. I was one who woke with the rooster's crow; I came down when it was only getting light enough to see when I had gotten all the way to that Braku Hill, you know? In childhood, fear doesn't seem to rise up in one's heart-and-mind, you know?66

There in that forest-you know the one? At that Middle River . . . the

65. One aspect of kinship that defines marriage possibilities among Parbatiya groups in Nepal.

66. Referring to the fact that few Tamang travel at night without fear, especially of ghosts (as we have seen from Nhanu's account). 
one we, when we $^{67}$ went on pilgrimage the other day, there in the forest near where those irrigated fields are now.

I would only get down there to the rise at the bottom of the village after sunset, only after dark. I had come running all the way from Firestonethat's what happened in my childhood, you know. That was how, coming down running, somehow too I wouldn't even get to eat.

\section{Our pilgrimage to Guptiswar}

Jyomo didn't need to remind me of our pilgrimage together; it remains one of the most significant and vivid memories of my first time in Stupahill. I had visited Stupahill before, but when I came to stay, David Holmberg had already been living there for some time. He had acquired a good deal of language and done considerable basic research, as well as having made friends and developed a local identity. I was, truly, an in-marrying bride: I knew no one well, was unable to communicate, and felt both uneasy about my dependence on him and worried that I might misstep or misspeak in ways that would jeopardize his work. When Jyomo invited me to go with her and a group of villagers on a pilgrimage to the sacred cave at Guptiswar, I eagerly accepted.

The preparations were elaborate. Even though the trail would take us by some of Jyomo's birth kin, who would host us generously, we were expected to offer some liquor and snacks in return. And, of course, there were many places along the way where there was no one to feed or house us. So the whole group made careful plans for pots, rice, lentils, spices, butter-in short, for everything we might need along the way.

Jyomo was particularly adamant that I take my sleeping bag. Since the season was getting quite warm and I thought that a light blanket might be enough, I wondered at her solicitousness-until the first night out. It became clear that she'd intended for me to unzip my bag so that several of us could sleep under it! I learned my first independent lesson in Tamang life: a good night's rest is not part of the Tamang idea of a good time; "party until you drop" is more the motto. Over the time I spent with Tamang friends, I came to realize that sleep, as we are wont to appreciate it-as a restorative respite from the day's cares-is not much known to Tamang people. They must cope with illness, bedbugs, lice, and rats. Women are expected to sleep with their children or grandchildren, and the fire needs constant tending. This is to say nothing of the many everyday disasters that do not wait until daylight to descend-the rainstorms that come through the roof, the roof that gets blown away by a windstorm, the animals that get loose, or get stuck, as a pregnant water buffalo once did in the gap between the back wall of our house and the

67. Jyomo and me, referring to our pilgrimage to Guptiswar cave. 
terrace above. With the many disruptions that are part of a normal Tamang village night, sleep is often little more than another form of exercise.

As we went from house to house, village to village, campsite to campsite, I discovered, among other things, the pleasures of night trekking. ${ }^{68}$ We would visit, drink, and eat all afternoon in one place, then, suddenly, just as it began to get too dark to see, someone would announce, "Let's go! It's time to go!" We would all heft our loads and start off for the next village. Night would fall. No one except me-again, at Jyomo's forethoughtful urging-had a flashlight or a lantern. Few had shoes, and most of those who did wore rubber thongs. As we stumbled through the dark, over uneven tracks, I was painfully aware how tired I was, and conscious, too, of how much harder were their everyday lives, that they would consider this fun. I would sing, both to keep myself going and to avoid the additional effort of conversation: "We Shall Overcome," and "Jacob's Ladder." Some months later, Jyomo, recounting our adventures, complained how tired she'd been. "But she," she said of me, "she was still singing!"

The Guptiswar pilgrimage was my initiation into Tamang life and the beginning of a bond with Jyomo and the other Stupahill villagers that remains very special to this day. For Jyomo, the trip had many more meanings. She got to visit her sister. She got to introduce her daughter's daughter to potential in-laws. She got to see the lamas and the bombos dance, and watch the revelry of the young people singing, dancing, and chasing each other with colored powders. She got away from everyday work. She got to see the sacred caves and celebrate the Tamang New Year in them. How many more associations all these locales had for her as she passed the place she was born and the place she first married, and saw old friends, long-standing kin, and old enemies.

TULARAM: Now, if you happen to meet that man, do you speak to him or not?

JYOMO: Why go on talking with such an evil one?

TULARAM: [Chuckles]

JYoмо: With him, with a person like that, if you happen to speak, even if you forget, why ... what right does he have to speak with me? There's nothing good about that one. Myself, I can't think of anything good about him. He never had any good words for me. Why would I go on talking with one who isn't even worth keeping except to throw away again?

What else is there to say? Even though whatever must be borne will be, who knows what happened? Who knows everything that happened? I'd rather forget. I did forget. And now, even though whatever was borne in those times when someone else spoke so harshly, no matter what is said now, someone else did speak so harshly then. Sometimes I cried; some-

68. David Holmberg's expression. 
times I laughed: so saying I would go on about my way. ${ }^{69} \mathrm{Up}$ to now, well, still up to now, even though I don't really think about it, still, forgetfulness hasn't arisen.

Then, over there, there, sometimes, from time to time, I'd go about working in the fields there and from time to time, I'd laugh and go about that way maybe. As soon as I'd get to the house, though, he'd speak harshly; I'd have to cry. He'd argue just like that; he'd go on like that.

I never got to stay in good comfort, you know. [Pause]

On and on. I kept on, sometimes crying, sometimes not. I never knew real comfort. How will that be forgotten? Where's the forgetfulness in that? He'd keep on speaking harshly; I'd keep on going. That's all. Where's forgetfulness?

ksM: One has to forget sorrow, they say, but sorrow won't be forgotten, they say.

Jyomo: After Father and Mother died, I'd go about crying. After my children died, I'd go about crying. Someone else would speak harshly; I'd go about crying. In order to forget all that, what? Well, I forgot it and, after forgetting, even so, I kept on going, but still forgetfulness would not come.

69. Literally, "would keep on walking." 